\title{
SHALLOW-WATER HABITAT CHANGE DETECTION OF KALEDUPA ISLAND, WAKATOBI NATIONAL PARK (WNP) FOR 14 YEARS
}

\section{DETEKSI PERUBAHAN HABITAT DASAR PERAIRAN PULAU KALEDUPA, TAMAN NASIONAL WAKATOBI (TNW) SELAMA 14 TAHUN}

\author{
Al Azhar ${ }^{1,2 *}$, Ario Damar ${ }^{3,5}$, Dietriech G. Bengen ${ }^{4}$, and Agus S. Atmadipoera ${ }^{4}$ \\ ${ }^{1}$ Graduate School of Coastal and Marine Resources Management, FPIK-IPB, Indonesia \\ ${ }^{2}$ LPPPTK KPTK, Ministry of Education and Culture, Indonesia \\ ${ }^{3}$ Department of Aquatic Resources Management, FPIK-IPB, Indonesia \\ ${ }^{4}$ Department of Marine Sciences and Technology, FPIK-IPB, Indonesia \\ ${ }^{5}$ Center for Coastal and Marine Resources Studies, IPB, Indonesia \\ *E-mail: adlyazhar@gmail.com
}

\begin{abstract}
Remote sensing method is helpful in spatially monitoring shallow water habitat conditions over a wide area. This study aimed to analyze the extent of changes in shallow water habitat of Kaledupa Island, Wakatobi National Park (WNP), for 14 years, from 2002 to 2016. The data of the research were Landsat 8 OLI (2016), Landsat 5TM (2009), and Landsat 7ETM ${ }^{+}$(2002), combined with in-situ and WNP data. Mahalanobis classification was used to produce shallow water habitat maps (live coral, dead coral, seagrass, and sand) and detect their changes. The results obtained that the changes occurred from 2002 to 2016 are live coral cover declines from 2217 ha to 2039 ha; dead coral cover goes down from 3327 ha to 2108 ha; sand area increases from 1201 ha to 1346 ha; and the area of seagrass habitat grows up from 4130 ha to 5294 ha. This method is a good analytical tool to assess the effectiveness of coral reef and seagrass ecosystem protection in Kaledupa Island waters and can be applied to three other main islands in TNW and small islets in Indonesia.
\end{abstract}

Keywords: remote sensing, shallow water habitat, change detection, kaledupa island

\section{ABSTRAK}

Metode penginderaan jauh sangat membantu dalam pemetaan kondisi habitat perairan dangkal secara spasial pada cakupan area yang luas. Penelitian ini bertujuan untuk menganalisis perubahan habitat perairan dangkal Pulau Kaledupa, Taman Nasional Wakatobi (TNW), selama 14 tahun, dari tahun 2002 hingga 2016. Data citra yang digunakan dalam penelitian ini adalah Landsat 8 OLI (2016), Landsat 5TM (2009), dan Landsat 7ETM+ (2002), yang dikombinasikan dengan data in-situ dan TNW. Klasifikasi Mahalanobis dimanfaatkan untuk memproduksi peta habitat perairan dangkal (karang hidup, karang mati, lamun, dan pasir) dan mendeteksi perubahannya. Hasil yang diperoleh bahwa perubahan yang terjadi dari tahun 2002 sampai 2016 adalah tutupan karang hidup menurun dari 2217 ha menjadi 2039 ha, tutupan karang mati juga menurun dari 3327 ha menjadi 2108 ha, luas pasir meningkat dari 1201 ha menjadi 1346 ha, area lamun naik dari 4130 ha menjadi 5294 ha. Metode ini merupakan alat analisis yang baik untuk menilai efektivitas upaya perlindungan ekosistem terumbu karang dan lamun di perairan Pulau Kaledupa, serta dapat diterapkan pada 3 pulau utama lainnya di TNW dan pulau-pulau kecil di Indonesia.

Keywords: penginderaan jauh, habitat perairan dangkal, deteksi perubahan, pulau kaledupa

\section{INTRODUCTION}

Wakatobi National Park (WNP) is one of a marine conservation area in Indonesia protecting coastal ecosystem.
Coral reefs, seagrass, and other coastal habitats are priority objects that must be conserved. Ecological functions of these habitats are spawning grounds, nursery grounds, and feeding grounds for marine 
biotas (Parrish, 1989; Nakamura et al., 2003; Dorenbosch et al., 2005; Guimaraes et al., 2012; Pogoreutz et al., 2012). However, on another hand, they are vulnerable being degraded. The susceptibilities are mainly affected by natural mortality and various anthropogenic activities in utilizing these resources (Hughes et al., 2007; Hughes and Stachowicz, 2011; Short et al., 2011; Kittinger et al., 2012). The WNP is designated as a world biosphere reserve being certainly frequent visited by international tourists (Buckley, 2004; Jimura, 2011). The more tourists come to this area, the more pressure happened in utilizing its coastal natural resources. This condition threatens the degradation of marine ecosystems. Elliott et al. (2001) and Caras and Pasternak (2009) states that shallow water habitat damages in Wakatobi are caused by increasing human population escalates natural resource pressures, coral mining for building materials, fishing using explosives and potassium cyanide, placing ship's anchors in coral reefs area, and settling fish traps in the sea floors. Fox and Caldwell (2006) emphasize that blast fishing had a huge impact on coral reef damages. The blast abandoned ruins of dead corals in the sea floor moving anywhere according to sea current direction or waves. These dead corals will be difficult being recovered, even though for several years. Whilst, according to Wilson et al. (2012) one of the coral damage causes in Wakatobi is an increasing seawater temperature that has a result of coral colony bleaching. Crabbe and Smith (2002, 2003, 2005, and 2006) state that sedimentation is a contributor of coral reefs damage in Kaledupa Island, especially in Sampela (Bajau Settlement).

A high productivity and the threat of natural resource degradation, making many marine experts interest to conduct researches in the WNP, especially in Kaledupa Island. Crabbe and Smith (2002, 2003, 2005, and 2006) observed habitats of coral reefs in three spots (Sampela, Kaledupa, and Hoga).
Periodically coral reefs and seagrass monitoring had been conducted by the WNP since 2008 until 2016. Studies about seagrass structure and its biota abundance had been done a lot by Unsworth et al. (2007a), Unsworth et al. (2007b), Unsworth et al. (2007c), and Cullen-Unsworth et al. (2014). Unfortunately, since the establishment of the National Park until now, there is not a spatial study to detect the success rate of coastal habitat protection efforts especially coral reefs, seagrass, and other shallow water habitats. The aim of this study was to analyze the extent of changes of shallow water habitats in Kaledupa Island for 14 years starting from 2002 to 2016. Results of this study are expected being an instrument for measuring the effectivity of conservation in Kaledupa Island, and a design recommendation of conservation area management. Methods and results of this study are able to be implemented to three other islands in Wakatobi (Wangi-wangi, Tomia, and Binongko), and other small islets in Indonesia.

\section{RESEARCH METHODS}

\subsection{Area of Study}

The WNP is initially well known as Tukang Besi Archipelago that is an acronym of four main island names such as WangiWangi (Wanci), Kaledupa, Tomia, and Binongko. It is located in the eastern of Kabupaten Buton regency that extends from north to south between $5^{\circ} 12^{\prime}-6^{\circ} 10^{\prime} \mathrm{S}$ and $123^{\circ} 20^{\prime}-124^{\circ} 39^{\prime} \mathrm{E}$. This study was focused on Kaledupa Island, and an area of study is described in Figure 1.

History of the WNP area management has been undergone several phases. Indonesia government assigned the WNP in 1996 through the Ministry of Forestry's decision (KepMen) Number 393/KPTSVI/1996, where the WNP itself had an early name as Wakatobi Islands National Park (WINP). 


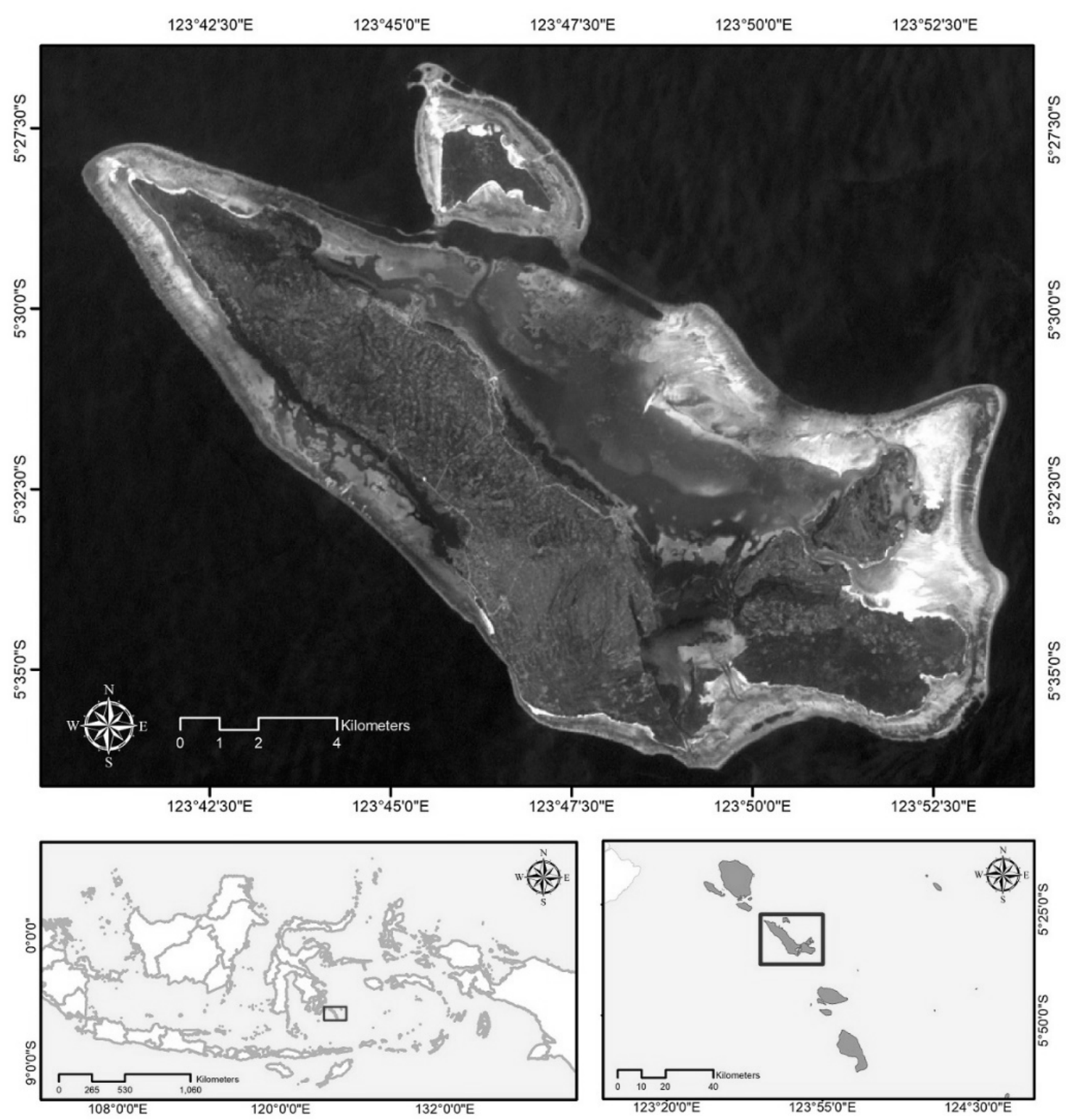

Figure 1. Area of study, Kaledupa Island.

According to the statistical data of the WNP (2013) that through the Ministry of Forestry's decision (KepMen) Number $7651 / \mathrm{KPTS}-\mathrm{II} / 2002$, the area covered about $\pm 1390 \mathrm{~km}^{2}$ that consisted of $97 \%$ ocean and $3 \%$ land. During those two phases, the WINP was a part of Buton Regency Administration. In 2003, by the Indonesia Law Number 29 of 2003, the WINP area was led being a new autonomous region as a name of Wakatobi Regency. The Wakatobi regency's borders coincided with the National Park area. Furthermore, in 2006, the Ministry of
Forestry issued the regulation number 29 by meaning to convert the name of WINP becoming the WNP. The WNP management model was conducted by zonation system. In 2007, the zonation of WNP area was revised by considering local community participation. The revision was aimed to be the protection efforts and the development of area were run simultaneously. Moreover, during 2012, the WNP was designed to become a world biosphere reserve in order being recognized by the world community. 


\subsection{Data Collection}

Data were used in this research consisted of the existing condition of benthic habitats (especially coral reefs, seagrass, and sands), and the Landsat imagery. Image data for analyzing change detection consisted of three series of Landsat data such as Landsat $7 \mathrm{ETM}^{+}$on October 25, 2002; Landsat 5TM on February 06, 2009; and Landsat 8 OLI on September 05, 2016. Data of benthic habitats were derived from field observation in October 2016 and the monitoring data resulted by the WNP. To produce a shallow water habitat map, several transects were conducted in the field survey. Total observation points are 100, comprises training area 40 and accuracy testing 60 . The distance of each observation point is 30 meters representing the spatial resolution of Landsat; supratidal, intertidal, and subtidal benthic environments; as well as changes in the appearance of spectral colors on satellite imagery. The geographic coordinates of the sampling points are selected by random stratified sampling.

The Landsat 8 OLI image has 11 spectral bands with several specification advantages and spectrum range lengths of electromagnetic waves. The new mounted specification in the Landsat 8 composes of band 1 (coastal/aerosol), band 9 (cirrus cloud), band 10 (thermal), and band 11 (thermal). The channels that have 30 meters spatial resolution are band 1 (coastal/ aerosol), band 2-4 (blue, green, red), band 5 (near infrared), band 6-7 (swir-1,2), and band 9 (cirrus). The band 8 (panchromatic) has 15 meters of resolution. Furthermore, bands 10 and 11 (thermal) are used to detect earth surface temperature difference having 100 meters of resolution. The second series, Landsat 7ETM+, provides 8 spectral bands and has a scene measurement of $170 \mathrm{~km} \mathrm{x}$ $183 \mathrm{~km}$ of coverage. These channels consist of visible light and infrared (band 1-5 and 7) with $30 \mathrm{~m}$ of spatial resolution, a panchromatic band (band 8) with 15 meters of spatial resolution, and near infrared band (band 6) with $60 \mathrm{~m}$ of spatial resolution, respectively. The last series, Landsat 5TM (Thematic Mapper), serves 7 spectral bands such as visible lights (band 1, 2, and 3), nearinfrared and medium infrared (band 4, 5, and 7), and thermal infrared (band 6). Six bands $(1,2,3,4,5$, and 7$)$ have $30 \mathrm{~m}$ of spatial resolution, and only one band (band 6) has $120 \mathrm{~m}$ of spatial resolution. Coverage extent of this image is about $175 \mathrm{~m} \mathrm{x} 185 \mathrm{~m}$ of scene wide.

\subsection{Change Detection}

Mahalanobis supervised classification was used to assist analyzing Landsat images. Change detection analysis was utilized to identify, describe, and calculate differences among images in the same scene with different recording times or different conditions (Lilesand et al., 2004). Analysis of change detection for coral reefs habitat in three image series used operation of raster calculator in the ArcMap 10 with the following simple formula (Wahiddin et al., 2014).

$P=K_{i} * 10^{t 1}+\cdots+K_{i} * 10^{t n}$

$P$ is a change detection, $K_{i}$ is habitat coverage into $-i, t$ is data series of recording images and $n$ is the number of image series.

Because of this research consisted of three image data series and four habitat classes of coral reefs, the form of change detection analysis is listed below. Habitat class $1=$ 111 , Habitat class $2=222$, Habitat class $3=$ 333, and Habitat class $4=444$.

If the pair number in each habitat class of resulting analysis undergoes change, there will be known its change every time in each image. Comparison of change detection was implemented in supervised classification maps of 2002 to 2009, and 2009 to 2016. Habitat degradation, therefore, was described based on changes of extent area in each habitat. The intended benthic habitat was 
categorized into four classes such as live coral, dead coral, seagrass, and sand.

\section{RESULTS AND DISCUSSION}

\subsection{Results of Analyzing the WNP Data}

This research was conducted by tracking resulted monitoring data of coastal resources of Kaledupa Island that had been collected by the WNP. The successful compiling data for exceeding an aim of this research was coral reefs habitat during 2009 to 2012. While seagrass habitat only was derived from monitoring data during 2008 to 2012. Those both data then were analyzed to elicit trend views of benthic habitat changes in Kaledupa Island since 2009 to 2016. In this research, the benthic habitat was divided into four class namely live coral, dead coral, sand, and seagrass. Classification of coral reefs habitat and its average cover percentage per year (20092016) is listed in Table 1. Coral reefs habitat was categorized into three class such as live coral (number 1 to 13 ), dead coral (number 14 and 15), and sand (16).

Table 1. Classification of coral habitat classes and its average percent covers per year.

\begin{tabular}{|c|c|c|c|c|c|c|c|c|}
\hline \multirow{2}{*}{ No } & \multirow{2}{*}{ Code } & \multirow{2}{*}{ Description } & \multicolumn{6}{|c|}{ Annual average percent cover } \\
\hline & & & 2009 & 2010 & 2011 & 2012 & 2015 & 2016 \\
\hline 1 & $\mathrm{ACB}$ & Acropora Branching & 4.88 & 2.33 & 1.91 & 1.17 & 0.29 & 0.54 \\
\hline 2 & $\mathrm{ACE}$ & a Encrusting & 0.00 & 0.17 & 0.00 & 0.75 & 0.42 & 0.00 \\
\hline 3 & $\mathrm{ACS}$ & a Submassive & 0.25 & 4.79 & 0.69 & 3.08 & 0.33 & 1.13 \\
\hline 4 & $\mathrm{ACT}$ & Acropora Tabulate & 1.71 & 2.29 & 0.25 & 1.92 & 0.58 & 0.13 \\
\hline 5 & $\mathrm{CB}$ & Hard Coral Branching & 3.38 & 1.00 & 1.31 & 0.17 & 1.17 & 0.71 \\
\hline 6 & $\mathrm{C}$ & Hard & 2.21 & 3.25 & 4.31 & 0.5 & 1.92 & 1.75 \\
\hline 7 & $\mathrm{CF}$ & Harc & 1.04 & 0.42 & 0.16 & 0.25 & 0.13 & 0.08 \\
\hline 8 & $\mathrm{CM}$ & Hard Coral Mass & 12.00 & 8.58 & 12.00 & 12.58 & 9.71 & 12.92 \\
\hline 9 & $\mathrm{CS}$ & $\begin{array}{l}\text { Hard Coral } \\
\text { Submassive }\end{array}$ & 5.13 & 1.13 & 3.06 & 0.92 & 5.46 & 4.00 \\
\hline 10 & CMR & Mushroom Coral & 0.29 & 0.33 & 0.3 & 0.25 & 0.46 & 0.17 \\
\hline 11 & CTU & (hard coral) & 0.46 & 0.63 & 0.00 & 0.00 & 0.00 & 0.00 \\
\hline 12 & CME & (fire coral) & 1.75 & 0.25 & 0.06 & 0.08 & 0.13 & 0.00 \\
\hline 13 & CHL & Heliopora (blue coral) & 0.29 & 0.00 & 0.00 & 0.08 & 0.21 & 0.00 \\
\hline 14 & $\mathrm{R}$ & Rubble & 7.54 & 12.25 & 4.19 & 11.59 & 3.54 & 9.67 \\
\hline 15 & $\mathrm{RCK}$ & Rock & 18.29 & 7.92 & 16.94 & 21.08 & 11.63 & 10.67 \\
\hline 16 & $\mathrm{~S}$ & Sand & 6.08 & 2.42 & 3.94 & 0.17 & 1.21 & 3.21 \\
\hline
\end{tabular}

Source: WNP data (2016) that had been processed.

Seagrass found in the Kaledupa Island is presented in Table 2. The seagrass data were the monitoring data resulted by WNP in 2015. Observations were taken in four shallow water locations such as Peropa, Kausari, Darawa, and Hoga. There were found seven species of seagrass existing in this area, Enhalus acoroides, Halodule uninervis, Cymodocea rotundata, Thalassia hemprichii, Halophila ovalis, Halodule pinnifolia, and Cymodocea serrulate.
Table 1 explains that live coral coverage according to the lifeform per year (2009-2016) is changing irregularly. The highest percent coverage is hard coral massive (CM). Percent coverage of the CM in 2009, 2010, 2012, 2015, and 2016, are $12 \%, 8.58 \%, 12 \%, 12.58 \%, 9.71 \%$. and $12.92 \%$, respectively. Whilst, the lower percent coverage consists of four lifeforms such as Acropora Encrusting (ACE), Tubipora (CTU), Millepora (CME), and 
Heliopora (CHL). In 2016, those four lifeforms are not seen their existence. This result indicates that those four lifeforms are difficult to live and to proliferate in the waters of Kaledupa Island. Percent cover of benthic habitat in the Kaledupa Island during 2009-2016 based on WNP data is able to be seen in Table 3.

Table 2. Seagrass species in Kaledupa Island.

\begin{tabular}{llccc}
\hline \multirow{2}{*}{ Seagrass Species } & \multicolumn{5}{c}{ Observation } \\
& \multicolumn{5}{c}{ Locations } \\
\cline { 2 - 5 } & A & B & C & D \\
\hline Enhalus acoroides & $\sqrt{ }$ & $\sqrt{ }$ & $\sqrt{ }$ & $\sqrt{ }$ \\
Halodule uninervis & $\sqrt{ }$ & & $\sqrt{ }$ & \\
Cymodocea & $\sqrt{ }$ & $\sqrt{ }$ & $\sqrt{ }$ & $\sqrt{ }$ \\
rotundata & & & & \\
Thalassia & & $\sqrt{ }$ & $\sqrt{ }$ & \\
hemprichii & & & $\sqrt{ }$ & $\sqrt{ }$ \\
Halophila ovalis & $\sqrt{ }$ & & $\sqrt{ }$ & \\
Halodule pinnifolia & $\sqrt{ }$ & & & \\
Cymodocea & $\sqrt{ }$ & $\sqrt{ }$ & $\sqrt{ }$ & $\sqrt{ }$ \\
serrulata & & & & \\
\hline Note: A Perapa
\end{tabular}

Note: $\mathrm{A}=$ Peropa, $\mathrm{B}=$ Kasuari, $\mathrm{C}=$ Darawa, $\mathrm{D}=$ Hoga (Source: WNP data, 2016)

Results of analyzing data of the WNP, the percent cover of live corals in Kaledupa Island waters for 2009 to 2016 is decreased. The percent cover of live coral in 2009, 2010, 2011, 2012, 2015, and 2016, are $33.38 \%, 25.17 \%, 24.06 \%, 21.75 \%, 20.79 \%$, and $21.42 \%$, respectively. In case, an average of its percent cover is about $1.71 \%$. It is different to live coral cover in Wangi-wangi, ranging 28-60\% (Yulius et al., 2015).

Change trend of the dead coral cover in Kaledupa is seen a decrease. The percent cover of dead coral in 2009, 2010, 2011, 2012, 2015, and 2016, are $25.83 \%, 20.17 \%$, $21.13 \%, 32.67 \%, \quad 15.17 \%$, and $20.34 \%$, respectively. An average rate of percent cover per year is about $0.78 \%$. Whilst, percent cover of sand tends to diminish from 2009 to 2016 and its annual average decrease rate is about $0.004 \%$. Conversely, Seagrass leads to the increasing percent cover in the period 2009 to 2011. Its annual average uplift is about $2.99 \%$.

Table 3. Percent cover of benthic habitats of Kaledupa Island year 2009-2016.

\begin{tabular}{cccc}
\hline \multirow{2}{*}{ Years } & \multicolumn{3}{c}{ Percent cover (\%) } \\
\cline { 2 - 4 } & Live Coral & Dead Coral & Sand \\
\hline 2009 & 33.38 & 25.83 & 6.08 \\
2010 & 25.17 & 20.17 & 2.42 \\
2011 & 24.06 & 21.13 & 3.94 \\
2012 & 21.75 & 32.67 & 0.17 \\
2015 & 20.79 & 15.17 & 1.21 \\
2016 & 21.42 & 20.34 & 3.21 \\
\hline Source: WNP data (2016) that had been \\
Processed.
\end{tabular}

Based on the Table 3, it is able to be seen clearly that the highest percent cover of live coral in Kaledupa Island from 2009 to 2016 only exceeds $33.38 \% \quad$ (2009). According to Giyanto et al. (2017), percent cover of live coral from $19 \%$ to $35 \%$ is categorized as a medium. However, the changing trend of percent cover of live coral that drops in 2016 becoming $21.42 \%$ indicates that it undergoes a continuously decreasing threat until to be under $19 \%$ threshold (leads to a low category). The existing data in 2016, the coral habitat of Kaledupa Island has a percent cover of rubble about $9.67 \%$ and turf algae about $1.67 \%$. When the percent cover of rubble exceeds $60 \%$ and turf algae eclipse $30 \%$, indicates the lower potential for coral reefs ecosystem recovery. Rubble is easily washed away by currents and waves, it is not an appropriate substrate for the coral larva to live and proliferate. Reciprocally turf alga, the existence of this alga detains corals living.

Giyanto et al. (2017) explain that the assessment of the coral health needs to be paid attention to two main components namely biotic component and fish coral. The biotic component consists of the existing condition of coral reefs (live coral cover) and the low coral resilience. While the fish coral 
component is the total biomass of fish coral consisting of many fish families such as Scaridae, Siganidae, Acanthuridae, Serranidae, Lutjanidae, Lethridae, dan Haemulidae. Referring to this assessment method, coral monitoring data conducted by the WNP in 2016 is able to be utilized to estimate the rate of coral health in Kaledupa Island. After analyzing process based on live coral cover, potential recovery, and category of coral fish in 2016, the coral health index is categorized high (point 9).

\subsection{Accuracy Test Results of Multispectral Image Analysis}

Benthic habitat analysis of Kaledupa

Island exhibits different results of period 2002 to 2016. Based on Mahalanobis classification, the overall thematic accuracy and kappa coefficient were higher in 2016 than 2009 and 2002. The analysis results of Landsat images in recording 2016 for both, overall thematic accuracy and kappa coefficient, were $71.67 \%$ and 0.62 , respectively. The lowest accuracy of Landsat image analysis was the recording 2002, having overall thematic accuracy and kappa coefficient were $60 \%$ and 0.46 , respectively. The low accuracy value of Landsat images in the recording 2002 was caused by ground truth sampling was conducted on 2016 which means the range of field observation and recording images was too long. For more details, the mapping accuracies of the benthic habitat of Kaledupa Island in the period of 2002, 2009, and 2016 based on supervised classification (Table 4).

Table 4. Mapping accuracy of the benthic habitat of Kaledupa Island on the period of 2002, 2009, and 2016.

\begin{tabular}{cccc}
\hline \multirow{2}{*}{ No } & Years & \multicolumn{2}{c}{ Accuracy Tests } \\
\cline { 3 - 4 } & & $\begin{array}{c}\text { Overall } \\
\text { accuracy }\end{array}$ & $\begin{array}{c}\text { Kappa } \\
\text { coefficient }\end{array}$ \\
\hline 1 & 2002 & $60.00 \%$ & 0.46 \\
2 & 2009 & $65.00 \%$ & 0.53 \\
3 & 2016 & $71.67 \%$ & 0.62 \\
\hline
\end{tabular}

\subsection{The Benthic Habitat Changes of Multispectral Image Analysis}

Results of detection analysis of the benthic habitat that had been conducted on three recording time periods (2002, 2009, and 2016) of Landsat images consisted in four coral habitats (live coral, dead coral, seagrass, and sand). Those classes have different change each other. The happened changes on the coral reefs area, live coral cover was degraded from 2002 to 2016 . This decrease from 2217 ha in 2002 became 2077 ha in 2009. During 2009 and 2016, it got off to be 2039 ha. The annual average live coral drop was about 13 ha or $7.14 \%$.

The same situation also happens on dead coral. The dead coral went down during 2002 to 2016. The dead coral cover was about 3327 ha (years 2002), it became 2144 ha (years 2009), and it dropped to be 2108 ha (years 2016). Its annual average decreasing was about 87.07 ha or about $7.14 \%$. A different trend happened on the sand class. This class rose from 1201 ha in 2002 to be 1405 ha in 2009. However, during 2009 to 2016, it descended from 1405 ha becoming 1346 ha. Overall, sand cover from 2002 to 2016 is increasing. Its change area is about 145 ha and its annual average change is about 10 ha. While seagrass habitat increases from 2002 to 2016. Its area is about 4130 ha (2002) to be 5247 ha (2009) and increases again in 2016 becoming 5294 ha. The area extension of seagrass cover during 2002 to 2016 is about 1164 ha and its annual average increase is about 83.14 ha. Benthic habitat changes in the waters of Kaledupa Island can be seen in Table 5 .

Table 5. Extent changes of the benthic habitats in the waters of Kaledupa Island in the period of 2002 to 2016.

\begin{tabular}{lllll}
\hline \multirow{2}{*}{ No } & Classification & \multicolumn{3}{c}{ Cover area (ha) } \\
\cline { 3 - 5 } & & Year & Year & Year \\
& 2002 & 2009 & 2016 \\
\hline 1 & Live coral & 2217 & 2077 & 2039 \\
2 & Seagrass & 4130 & 5247 & 5294 \\
\hline
\end{tabular}




\begin{tabular}{lllll}
\hline \multirow{2}{*}{ No } & Classification & \multicolumn{3}{c}{ Cover area (ha) } \\
\cline { 3 - 5 } & & Year & Year & Year \\
& 2002 & 2009 & 2016 \\
\hline 3 & Sand & 1201 & 1405 & 1346 \\
4 & Dead coral & 3327 & 2144 & 2108 \\
\hline
\end{tabular}

Extent changes of each class from 2002 to 2016 are various. The very significant change happens 2002 to 2009. Decreasing dead coral exceeds 1183 ha and live coral is about 140 ha. Contrarily, seagrass and sand covers increased where seagrass increases significantly about 1117 ha, and sand increases only about 204 ha. Those all benthic habitats are not so significantly increased during the period of 2009 to 2016. These three classes such as live coral, dead coral, and sand, decrease with extent changes about 36 ha, 37 ha, and 59 ha, respectively. Those classes are different with seagrass class, where it increases although not significantly. Extension of seagrass is about 47 ha. The spatial distributions of cover changes of benthic habitats in the Kaledupa Island in years 2002 and 2016 are displayed in the Figure 2 and 3.

Based on Figure 2, the resulted benthic habitat map from analyzing Landsat images in 2002 can be seen that many live corals are distributed in the slope areas of Kaledupa Island. While dead corals are spread in almost all shallow waters. Sands are swept in the waters of Derawa and Sombano. Furthermore, seagrasses are hugely grown in the southern of Kaledupa Island and around Langge village.

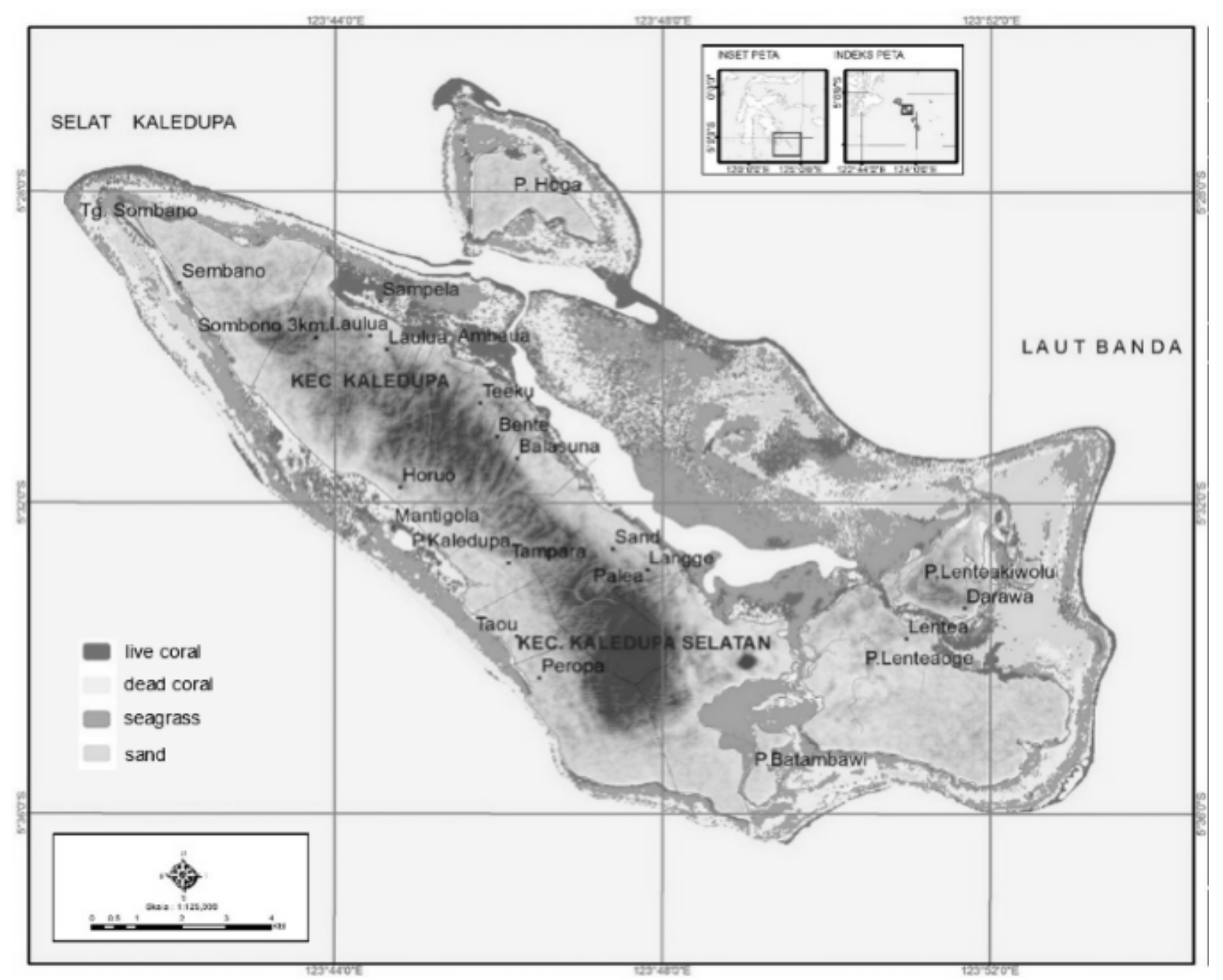

Figure 2. Benthic habitat map of Kaledupa Island in the years 2002. 
The coral degradation in the Kaledupa island has occurred long time before 2002. Elliot et al. (2001) in their writing explains the coral degradation in the surrounding Kaledupa Island are caused by coral mining for building materials, blast fishing, and cyanide uses for fishing, taking shells and scallops in the coral reefs area, fisherman's boat activities, oil drainage leaning on the harbours, and waste disposal from residential areas. The coral mining was a legal activity until 1992. The local communities started to grub up corals for their houses' foundation since the $1960 \mathrm{~s}$, for establishing house fences the 1960s and 1970s, and for establishing roads in 1970s and 1980s (Elliot et al., 2001). The corals were selected because they were considered very strong and able to be long-lasting. Caras and Pasternak (2009) explain the mined coral areas causing live corals, percent dead corals, species richness and hard corals abundance, are greatly reduced.

Fishing used explosives in the waters of Kaledupa Island starting from around 1943. Fishermen assumed that blast fishing was able to get more fish. According to Elliot et al. (2001), in 1997, there was still found fisherman using explosives materials for fishing. In 1998, local people claimed to have not used explosives and cyanide for fishing. Furthermore, a research conducted in 2000 resulting in that explosives and cyanide uses were decreased. Other factors of habitat coral reefs damages are caused by boat anchors and fisherman boats activities in coral reefs areas. Kaledupa Island has a flatted seafloor topography. Therefore, when the low tide occurs, the passing boat of fisherman will run aground in the coral reefs areas so that fisherman uses a bamboo stick to push the boat. The bamboo stick use clearly damages and destructs coral reefs.

The map was produced by using Landsat images of 2002 to 2009 indicating the live corals was diminished. The live corals priorly were distributed in the waters around Langge and Derawa, are being degraded. So, the extent of dead corals become reduced. It can be seen in the map above that the waters around Bente Village and Balasuna Village in 2002, there are any distributions of dead corals, and those areas are replaced by seagrass habitat in 2009. This is to be expected that the dead coral fragments are overgrown by algae and then become proper habitats for seagrasses to live. In 2009, the seagrass cover rises drastically. Several areas that had been substituted to be seagrass habitats are southern Kaledupa Island, Batambawi, Lenteaoge, and Ambeuwa. According to Caras and Pasternak (2009), Clifton (2013), badly damage corals caused by coral mining or blast fishing are mostly failed to be recovered even though the damages happen in long-term. Tourism activity also becomes a cause of coral damage (Clifton, 2013). Fox and Caldwell (2006) explain that damage coral needs hundreds of years for being recovery.

The shrinkage of coral habitat extension from 2002 to 2009 due to many factors. Tukang Besi Archipelago previously was only a part of Buton Regency, and it became a new autonomous as Wakatobi Regency based on the Indonesia Law No. 29 of 2002. Through a definitive status of the area, it would open up many new jobs massively. This condition interested many people from other areas coming to look for jobs. According to BPS Wakatobi (2017), the number of population of Wakatobi in the period of 2000 to 2003 was increasing significantly about 1071 people or about 357 persons per year. The more human population, the more threats of coastal resources use destructively.

Another factor of degrading coral reefs in the Island since 2002 to 2009 is an attack of coral diseases. Based on a resulted research by Haapkyla et al. (2007), coral reefs in Kaledupa Island was attacked by diseases. In the research, samplings conducted in 2005 found that there were five conditions of coral reefs such as white syndrome, tumor, green spot, green band, 
and pigmented spots. About 12352 of coral colonies from 32 groups of taxonomy were found in an area about $3600 \mathrm{~m}^{2}$. Then, 1627 $(13.2 \%)$ of coral colonies indicated signs of pathology, including bleaching, predation, diseases, and unknown pathologies. The most common types of pathology were previously unknown $(9.7 \%$ of the colony) covered unclassified condition $(3.0 \%)$, green spot $(2.8 \%)$, pigmented spots $(1.9 \%)$, greenband $(1.2 \%)$, and flatworm infestation $(0.8 \%)$. The next most frequent syndrome was coral bleaching ( $2.0 \%$ of the colony), followed by signs of predation (1.0\%). Signs relating to coral diseases that had been known including white syndrome and tumor were only observed for $0.6 \%$ of colonies encountered.

Figure 3 displays benthic habitat maps of 2016 produced by analyzing Landsat images of 2009 to 2016. In the map shows that the live coral distribution goes down. Dead coral degradation in the period of 2002 to 2009 can see Table 5. In reverse, seagrass cover goes up. One of causes of coral habitat degradation from 2009 to 2016 is coral bleaching that happened during 2010 to 2011. Global warming causes sea surface temperature rise which impacts on coral bleaching (Setiawan et al., 2017). Sea surface temperature exceeded normal level during 9 weeks starting from March to May in 2010. The bleached corals reached an average of $65 \%$ and coral death was estimated in average of $<1 \%$ (Wilson et al., 2012). Coral bleaching and coral death happened also on Kaledupa Island. The compositions of impacted corals were about $30-40 \%$. Furthermore, there were found fishermen going fishing using potassium cyanide in 2010, and explosives in 2011. Based on statistical data of the WNP (2013), perpetrators used potassium cyanide were local people of Kaledupa. They went fishing on February 16, 2010. While perpetrators used explosives for fishing were outside fishermen coming from Konawe Regency, Southeast Sulawesi. The blast fishing happened in the marine protected zone of Kaledupa waters on December 20, 2011.

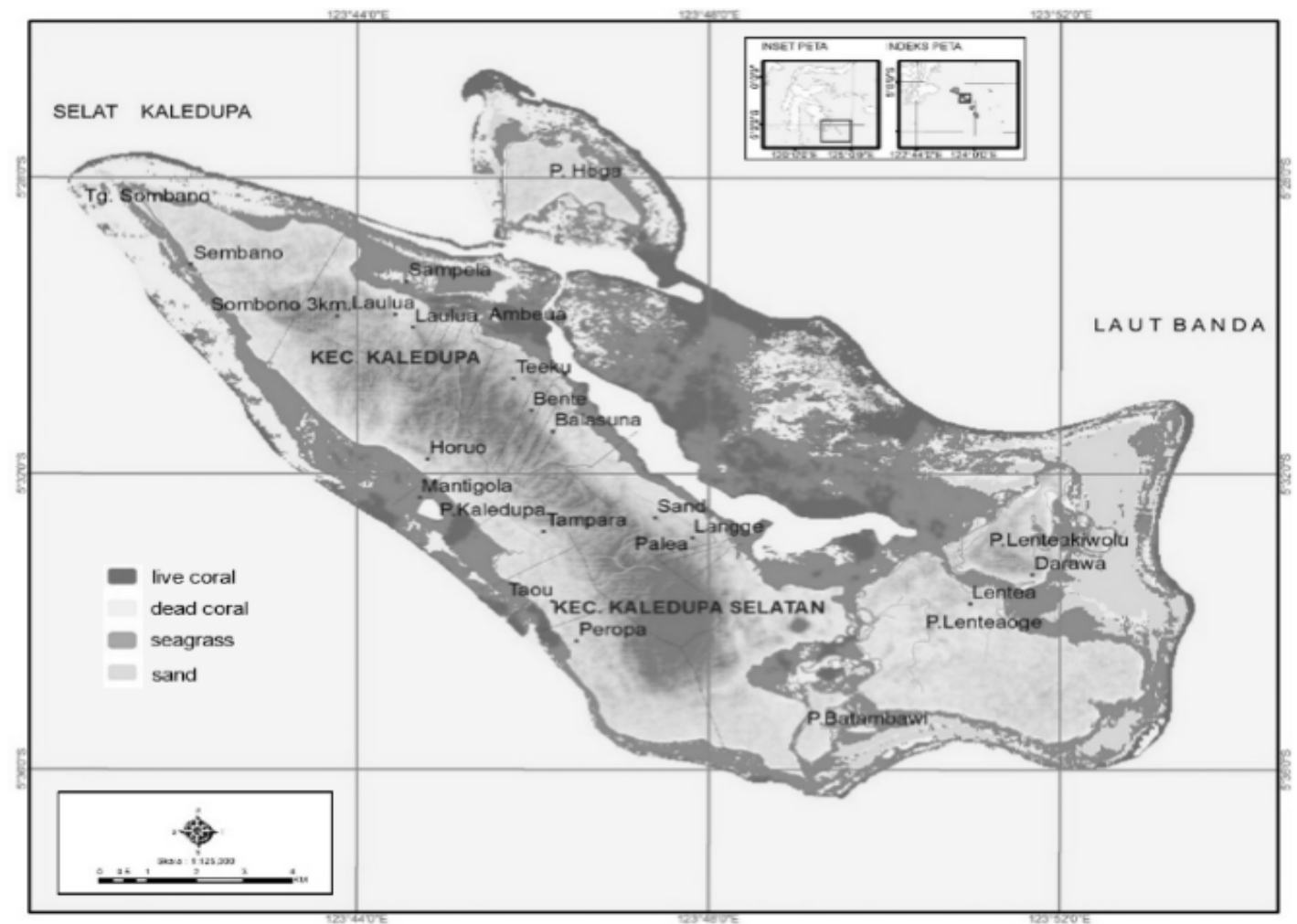

Figure 3. Benthic habitat map of Kaledupa Island in the year 2016. 
Important factors that should be emphasized for recovering the destroyed corals are recovery times is long enough, and fragment resource and adequately vegetative structure of coral (Hughes and Tanner, 2000; Knowlton, 2001; Coles and Brown, 2007; Done et al., 2007; Scopelitis et al., 2009; Caras and Pasternak 2009). Littler et al. (2006) state that the existence of fleshy alga will inhibit coral reefs growth. Presence of macroalga is greatly influenced by nutrient supply and herbivorous animals. When nutrients diminished and the herbivorous animals increased, the fleshy alga is reduced. According to Mumby et al. (2016), the depletion of the herbivorous animal in coral reefs areas will cause phytoplankton blooming and relieve coral recruitment. Mwachireya et al. (2017) says that sediment and nutrient support turf alga and another macroalga, however, decrease the density of coral algae and coral recruitment density. Sangil and Guzman (2018) explain that macroalga abundance and the existence of coral reefs in every area will be different depending on environmental condition and ecosystems in the area. Habitat biodiversity of Kaledupa Island in overall should be studied deeply as an input in order to be used for recovering the damaged habitats. In conducting the effort, local communities' participation should be considered in managing the conservation areas in Kaledupa Island. Communities participation is a model of sustainable environmental conservation management (Masud et al., 2017).

\section{CONCLUSION}

Multispectral images (Landsat 8 OLI, Landsat $7 \mathrm{ETM}^{+}$, and Landsat $5 \mathrm{TM}$ ) are particularly useful for detecting changes in shallow water marine habitats. The supervised classification of these images is obtained that coral reef cover decreases from 2217 ha in years 2002 to 2039 ha in 2016. The annual average live coral decrease is about 13 ha or $7.14 \%$. The dead coral has declined from 2002 to 2016. In 2002, the dead coral cover is about 3327 ha, and in 2009 it becomes 2144 ha, and in 2016, it reduces also to be 2108 ha. Its annual average drop-off is about 87.07 ha or about $7.14 \%$. The different trend happens on the sand. This class increases from 1201 ha in 2002 to 1346 ha in 2016. While seagrass habitat increases from 2002 to 2016. The area extension of seagrass cover during 2002 to 2016 is about 1164 ha and its annual average increase is about 83.14 ha.

\section{ACKNOWLEDGMENT}

This article is a part of doctoral research from Study Program of Coastal and Marine Resources Management, Bogor Agricultural University (IPB). Thanks to various parties that had supported in finishing this research. The authors would like to thank Ministry of Education and Culture (Indonesia) that has provided scholarships. Field data retrieval like ground truth in the waters of Kaledupa Island was assisted by local fishermen and members of Forkani (especially to Hasanuddin) who had provided any information about benthic habitats. Ari Anggoro who had contributed and shared his knowledge about remote sensing in mapping benthic habitats of shallow waters. Thanks also are delivered to The WNP that had provided resource monitoring data in conservation areas of Wakatobi, and Wakatobi Regency government that had supported this research by supplying complementary data.

\section{REFERENCES}

Balai Taman Nasional Wakatobi. 2013. Statistik balai taman nasional wakatobi. Balai Taman Nasional Wakatobi. Wakatobi. $104 \mathrm{hlm}$.

Badan Pusat Statistik Wakatobi. 2017. Kabupaten wakatobi dalam angka 2017. Badan Pusat Statistik 
Kabupaten Wakatobi. Wakatobi. 302 hlm.

Buckley, R.C. 2004. The effects of world heritage listing on tourism to Australian national parks. $J$. of Sustainable Tourism, 12(1):70-84. http://dx.doi.org/10.1080/0966958040 8667225.

Caras, T. and Z. Pasternak. 2009. Long-term environmental impact of coral mining at the Wakatobi marine park, Indonesia. Ocean \& Coastal Management, 52:539-544. http://dx. doi.org/10.1016/j.ocecoaman.2009.08 .006 .

Clifton, J. 2013. Refocusing conservation through a cultural lens: improving governance in the Wakatobi Nasional Park, Indonesia. Marine policy, 41:80-86. http://dx.doi.org/10.1016/ j.marpol.2012.12.015.

Coles, S. and E. Brown. 2007. Twenty-five years of change in coral coverage on a hurricane impacted reef in Hawaii: the importance of recruitment. Coral Reefs, 26:705-717.

Crabbe, M.J.C. and D.J. Smith. 2002. Comparison of two reef sites in the Wakatobi Marine National Park (SE Sulawesi, Indonesia) using digital image analysis. Coral reefs, 21: 242244. http://dx.doi.org/10.1007/s00338 -002-0250-9.

Crabbe, M.J.C. and D.J. Smith. 2003. Computer modelling and estimation of recruitment patterns of nonbranching coral colonies at three sites in the Wakatobi Marina Park, S.E. Sulawesi, Indonesia; implications for coral reef conservation. Computational Biology and Chemistry, 27:17-27.

Crabbe, M.J.C. and D.J. Smith. 2005. Sediment impacts on growth rates of Acropora and Porites corals from fringing reefs of Sulawesi, Indonesia. Coral reefs. http://dx.doi.org/ 10.1007/s00338-005-0004-6.
Crabbe, M.J.C. and D.J. Smith. 2006. Modellling variations in corallite morphology of Galaxea fascicularis corals colonies with depth and light on coastal fringing reefs in the Wakatobi Marine Nasional Park (S.E. Sulawesi, Indonesia). Computational Biology and Chemistry, 30:155-159. http://dx.doi.org/10.1016/j.compbiolc hem.2005.11.004.

Cullen-Unsworth, L.C., L.M. Nordlund, J. Paddock, S. Baker, L.J. McKenzie, and R.K.F. Unsworth. 2014. Seagrass meadows globally as a coupled social-ecological system: implications for human wellbeing. Marine Pollution Bulletin, 83:387-397. http://dx.doi.org/10.1016/j.marpolbul. 2013.06.001.

Done, T., E. Turak, M. Wakeford, L. DeVantier, A. McDonald, and D. Fisk. 2007. Decadal changes in turbid-water coral communities at Pandora Reef: loss of resilience or too soon to tell? Coral Reefs, 26(4):789805 . http://dx.doi.org/10.1007/ s00338-007-0265-3.

Dorenbosch, M., M.G.G. Grol, M.J.A. Christianen, I. Nagelkerken, and G. Van der Velde. 2005. Indo-Pacific seagrass beds and mangroves contribute to fish density and diversity on adjacent coral reefs. Mar. Ecol. Prog. Ser., 302:63-76. http://dx.doi.org/10.3354/meps30206 3.

Elliot, G.B, Mitchell, B., Wiltshire, A., Manan, Wismer. 2001. Community Participation in Marine Protected Area Management: Wakatobi National Park, Sulawesi, Indonesia. Coastal Management, 29:295-316. http://dx.doi.org/10.1080/0892075017 50475118.

Fox, H.E., and R.L. Caldwell. 2006. Recovery from blast-fishing: A tale of two scales. Ecol. Appl., 16(5):16311635. 
Giyanto, P. Mumby, N. Dhewani, M. Abrar, dan M.Y. Iswari. 2017. Indeks kesehatan terumbu karang Indonesia. Pusat Penelitian OseanografiLembaga Ilmu Pengetahuan Indonesia. PT. Media Sains Nasional. Jakarta. 109 p.

Guimaraes, M.H.M.E., A.H. Cunha, R.L. Nzinga, and J.F. Marques. 2012. The distribution of seagrass (zostera noltii) in the ria formosa lagoon system and the implications of clam farming on its conservation. $J$. for Nature Conservation, 20:30-40. http://dx.doi.org/10.1016/j.jnc.2011.0 7.005 .

Haapkyla, J., A.S. Seymour, J. Trebilco, and D. Smith. 2007. Coral disease prevalence and coral health in the Wakatobi Marine Park, south-east Sulawesi, Indonesia. J. Mar. Biol. Ass. U.K., 87:403-414. http://dx.doi. org/10.1017/S0025315407055828.

Hughes, T., and J. Tanner. 2000. Recruitment failure, life histories, and long-term decline of caribbean corals. Ecology, 81:2250-2263. http://dx.doi.org/10. 2307/177112.

Hughes, T.P., M.J. Rodrigues, D.R. Bellwood, D. Ceccarelli, O. HoeghGuldberg, L. McCook, N. Moltschaniwsky, M.S. Pratchett, R.S. Steneck, and B. Willis. 2007. Phase shifts, herbivory, and the resilience of coral reefs to climate change. Current Biology, 17:1-6. http://dx.doi.org/10. 1016/j.cub.2006.12.049.

Hughes, A.R., and J.J. Stachowicz. 2011. Seagrass genotypic diversity increases disturbance response via complementarity and dominance. $J$. of Ecology, 99:445-453. http://dx.doi. org/10.1111/j.13652745.2010.01767. $\mathrm{x}$.

Jimura, T. 2011. The impact of world heritage site designation on local communities - a case study of ogimachi, shirakawa-mura, Japan.
Tourism Management, 32:288-296. http://dx.doi.org/10.1016/j.tourman.2 010.02.005.

Kittinger, J.N., E.M. Finkbeiner, E.W. Glazier, and L.B. Crowder. 2012. Human dimensions of coral reef social-ecological systems. Ecology and Society, 17. http://dx.doi.org/ 10.5751/ES-05115-170417.

Knowlton, N. 2001. Who are the players on coral reefs and does it matter? The importance of coral taxonomy for coral reef management. Bulletin of Marine Science, 69:305-308.

Littler, M.M., D.S. Littler, and B.L. Brooks. 2006. Harmful algae on tropical reefs: bottom-up eutrophication and topdownl herbivory. Harmful Algae, 5:565-585. http://dx.doi.org/10.1016 /j.hal.2005.11.003.

Masud, M.M., A.M. Aldkhil, A.A. Nassani, and M.N. Azam. 2017. Communitybased ecotourism management for sustainable development of marine protected areas in Malaysia. Ocean \& Coastal Management, 136:104-112. http://dx.doi.org/10.1016/j.ocecoaman .2016.11.023.

Mumby, P.J., R.S. Steneck, M. Adjeroud, and S.N. Arnold. 2016. High resilience mask underlying sensitivity to algal phase shifts of pacific coral reefs. Oikos, 125:644-655. http://dx. doi.org/10.1111/oik.02673.

Mwachireya, S.A., A.M. Nzioka, and D.N. Mutiso. 2017. Coral recruit-algae interactions in coral reef lagoons are mediated by revirine influences. International J. of Ecology, 2017:110. http://dx.doi.org/10.1155/2017 $/ 1351854$.

Nakamura, Y., M. Horinouchi, T. Nakai, and M. Sano. 2003. Food habits of fishes in a seagrass bed on a fringing coral reef at iriomote island, southern japan. Ichthyol. Res., 50(1):15-22. http://dx.doi.org/10.1007/s10228030 0002 . 
Parrish, J.D. 1989. Fish communities of interating shallow-water habitats in tropical oceanic regions. Mar. Ecol. Prog. Ser., 58:143-160.

Pogoreutz, C., D. Kneer, M. Litaay, H. Asmus, and H. Ahnelt. 2012. The influence of canopy structure and tidal level on fish assemblages in tropical Southeast Asian seagrass meadows. Estuarine, Coastal and Shelf Science, 107:58-68. http://dx. doi.org/10.1016/j.ecss.2012.04.022.

Sangil, C., and H.M. Guzman. 2016. Mocroalgal communities on multistressed coral reefs in the Caribbean: long-term changes, spatial variations, and relationships with environmental variables. J. of Sea Research, 117:719. http://dx.doi.org/10.1016/j.seares .2016.09.001.

Scopelitis, J., S. Andréfouet, S. Phinn, P. Chabanet, O. Naim, C. Tourrand, and T. Done. 2009. Changes of coral communities over 35 years: Integrating in situ and remote-sensing data on Saint-Leu Reef (la Reunion, Indian Ocean). Estuarine, Coastal and Shelf Science, 84:342-352. http://dx.doi.o rg/10.1016/j.ecss.2009.04.030.

Setiawan, F., A. Muttaqin, S.A. Tarigan, Muhidin, Hotmariyah, A. Sabil, dan J. Pinkan. 2017. Pemutihan karang akibat pemanasan global tahun 2016 terhadap ekosistem terumbu karang: studi kasus di TWP Gili Matra (Gili Air, Gili Meno, dan Gili Trawangan) Provinsi NTB. J. of Fisheries and Marine Science, 1(2):39-54.

Short, F.T., B. Polidoro, S.R. Livingstone, K.E. Carpenter, S. Bandeira, J.S. Bujang, H.P. Calumpong, T.J.B. Carruthers, M.D. Fortes, Y.A. La Nafie, I.M. Nasution, R.J. Orth, A. Prathep, M. Waycott, and J.C. Zieman. 2011. Extinction risk assessment of the world's seagrass species. Biological Conser-vation, 144:1961-1971. http://dx.doi.org/10. 1016/j.biocon.2011.04.010.

Unsworth, R.K.F., E. Wylie, D.J. Smith, and J.J. Bell. 2007a. Diel trophic structuring of seagrass bed fish assemblages in the Wakatobi Marine National Park, Indonesia. Estuarine, Coastal and Shelf Science, 72:81-88. http://dx. doi.org/10.1016/j.ecss.2006.10.006.

Unsworth, R.K.F., S.D. Grave, J. Jompa, D.J. Smith, and J.J. Bell. 2007b. Faunal relationships with seagrass habitat structure: a case study using shrimp from the Indo-Pacific. Marine and Freshwater Research, 58:1008-1018. http://dx.doi.org/10.1071/MF07058.

Unsworth, R.K.F., J.D. Taylor, A. Powell, J.J. Bell, and D.J. Smith. 2007c. The contribution of scarid herbivory to seagrass ecosystem dynamics in the Indo-Pacific. Estuarine, Coastal and Shelf Science, 74:53-62. http://dx. doi.org/10.1016/j.ecss.2007.04.001.

Wahiddin, N., V.P. Siregar, B. Nababan, I. Jaya, S. Wouthuyzen. 2014. Deteksi perubahan habitat terumbu karang menggunakan citra landsat di Pulau Morotai Provinsi Maluku Utara. J. Ilmu dan Teknologi Kelautan Tropis, 6(2):507-524.

Wilson, J.R., R.L. Ardiwijaya, and R. Prasetia. 2012. A study of the impact of the 2010 coral bleaching event on coral communities in Wakatobi Nasional Park. The Nature Conservancy. $25 \mathrm{p}$.

Yulius, N. Novianti, T. Arifin, H.L. Salim, M. Ramdhan, dan D. Purbani. 2015. Distribusi spasial terumbu karang di perairan Pulau Wangi-wangi, Wakatobi. J. Ilmu dan Teknologi Kelautan Tropis, 7(1):59-69.
Diterima
: 17 Mei 2018
Direview $\quad: 19 \mathrm{Mei} 2018$
Disetujui : 05 Juli 2018 